\title{
Effects of Probiotics on Growth and Survival of Shrimp (Penaeus monodon) in Coastal Pond at Khulna, Bangladesh
}

\author{
M. I. Hossain ${ }^{1}$, M. M. Kamal ${ }^{1}$, M. A. Mannan ${ }^{2}$, M. A. B. Bhuyain ${ }^{3}$, and M. I. Hossain ${ }^{4 *}$ \\ ${ }^{1}$ Gazi Fish Culture Ltd. Dacope, Khulna \\ ${ }^{2}$ Faculty of Fisheries, Bangladesh Agricultural University, Mymensingh \\ ${ }^{3}$ Institute of Marine Sciences \& Fisheries, University of Chittagong \\ ${ }^{4}$ Department of Fisheries, University of Rajshahi, Rajshahi
}

Received 18 September 2012, accepted in final revised form 28 February 2013

\begin{abstract}
The study was carried out for 138 days to know the growth and survival rate of $P$. monodon by applying probiotics in Gazi Fish Culture Ltd. Dacope, Khulna, Bangladesh. Six experimental ponds $\left(4000 \mathrm{~m}^{2}\right.$ in size i.e. one acre) were selected of which three were probiotic ponds and three were controlled. After pond preparation, $\mathrm{PL}_{15}$ (average weight of each $4.75 \pm 0.09 \mathrm{~g}$ ) was stocked at the rate of 13 per $\mathrm{m}^{2}$ following polymerase chain reaction (PCR) test. CP NASA shrimp feed was used during the study period. Transparency, salinity, $\mathrm{pH}$, dissolved oxygen (DO), temperature, total Ammonia Nitrogen (TAN) were recorded by standard measurements. The average final body weight of the harvested shrimp is $37.67 \pm 1.15 \mathrm{~g}$ in probiotics ponds and $27.33 \pm 0.58 \mathrm{~g}$ in controlled ponds and the difference was significant $(P<0.01)$ between these two productions. The average survival rate was $90.67 \pm 1.15 \%$ in probiotic pond and $71.00 \pm 3.0 \%$ in controlled pond. The average daily gain (ADG) in weight was $0.27 \pm 0.01 \mathrm{~g}$ and $0.19 \pm 0.01 \mathrm{~g}$ in probiotic and controlled ponds, respectively. The result showed that probiotic plays an important role in maintaining water quality parameters, soil quality and health management as well as increases the growth and survival of shrimp.
\end{abstract}

Key words: Probiotics; P. monodon; Water quality parameter; Growth rate; Survival rate.

() 2013 JSR Publications. ISSN: 2070-0237 (Print); 2070-0245 (Online). All rights reserved.

doi: http://dx.doi.org/10.3329/jsr.v5i2.11815 J. Sci. Res. 5 (2), 363-370 (2013)

\section{Introduction}

Probiotics are live nonpathogenic microorganisms that provide colonization resistance to the pathogenic microbes and thus are effective in prevention and treatment of some diseases. Fuller [1] defined probiotics as live microbial feed supplements which beneficially affect the host by improving its intestinal microbial balance. Probiotics, lactic acid bacteria and Bacillus spp. as 'bio-friendly agents' can be introduced into the culture environment to control and compete with pathogenic bacteria as well as to promote the growth of the cultured organisms

\footnotetext{
*Corresponding author: bitanrubd@yahoo.com
} 
[2]. The use of beneficial bacteria (probiotics) to displace pathogens by competitive processes is being used in the animal industry as a better remedy than administering antibiotics and is now gaining acceptance for the control of pathogens in aquaculture [3]. Shrimp (P. monodon) play an important role in the economy of Bangladesh. Shrimp is of great importance in earning foreign exchange and also to meet up protein demand and to solve unemployment problem for the increasing population. Among the exportable fish and fisheries items of Bangladesh the contribution of shrimp is 57\% [4]. One of the major problems at present in the shrimp aquaculture is the microbial disease caused by self-pond pollution [5]. Probiotic bacteria improve the health of shrimp by controlling pathogens and improving water quality by modifying the microbial community composition of water [6]. The main probiotic bacteria documented in shrimp grow-out are Bacillus spp. strains [7-8] such as Bacillus subtilis [9-10] or Gram-negative bacteria strains [11-13]. Several reviews [5, 10-11, 14-21] detail the various developments made in the use of probiotics in aquatic cultured species, including shrimp. Based on the previous research on probiotics it is suggested that the use of probiotic bacteria in aquaculture has tremendous scope and the study on application of probiotics in aquaculture has a glorious future [22-23]. The present study, therefore, has been conducted with the objective of supplementing probiotics in the diet of $P$. monodon and assessing their growth performance and survival rate by semi intensive culture in Bangladesh.

\section{Materials and Methods}

The study was done in Gazi Fish culture Ltd., Dacope, Khulna, Bangladesh. The culture was done for 138 days. Initially ponds were re-excavated and allowed to sun dry to increase the capacity of oxidation of hydrogen sulphide and to eliminate other obnoxious gases. The soil $\mathrm{pH}$ was recorded in the pond by $\mathrm{pH}$ meter. The average $\mathrm{pH}$ was calculated and required amount of lime was applied to maintain the optimum $\mathrm{pH}$. The ponds were fenced by blue net to prevent entering virus carrier species. During the high tidal period the ponds were filling in the water by filtration with small mesh size filter net. The initial water levels in the ponds were maintained at $1.5 \mathrm{~m}$ level. After filling the pond, crab net was fitting surrounding the ponds. Ponds were bleached at $60 \mathrm{ppm}$ bleaching, containing 30\% chlorine. Four paddle wheel aerators (2 HP each) were set in the four corner position of the pond. For plankton growing the organic compounds and minerals such as rice bran, fish meal, molasses, yeast, dolomite, nutrilake, a-soil and soda mix were applied in the probiotics and controlled ponds.

Water salinity, temperature, transparency, alkalinity, dissolve oxygen, $\mathrm{pH}$, TAN were measured and monitored regularly. The water level was measured by using a hand made wooden scale with $\mathrm{cm}$ marking. The water salinity of the pond was measured by using a hand refrectometer (Erma-Japan). The pH, alkalinity, total ammonia nitrogen (TAN) of the pond water was recorded by using $\mathrm{pH}$ test kit, alkalinity kit and ammonia test kit respectively (Advance Pharma, Thailand). Water temperature was measured by using a standard centigrade thermometer. The dissolved oxygen (DO) was estimated by D. O. test kit (Advance Pharma, Thailand). Transparency was observed by using a secchi disc. 
Ponds were ready for stocking after three weeks. Then PCR tested healthy P. monodon seeds $\left(\mathrm{PL}_{15}\right)$ which were purchased from a commercial hatchery were stocked at a density of $13 / \mathrm{m}^{2}$. Before stocking, the seeds were acclimatized to the pond environment. For this the seed bags were allowed to float on the water surface in each pond for 30 minutes in order to adjust the temperature. The bags were opened and the pond water was introduced slowly by sprinkling into the bags for 60 minutes to equalize with pond water parameters. After acclimatization, seeds were released slowly to the ponds water.

During the culture period different types of soil, water and feed probiotics such as Super PS, Super biotic, Pro-w, mutagen, zymatin and Pro-2 were applied for maintaining soil, water quality and feed consumption of shrimp in probiotics ponds. After 138 days of rearing, shrimp was harvested by pumping the pond.

The feeding schedule was based on the feed chart given by the CP Aquaculture (India) Pvt. Ltd. Company. Later the feeding was adjusted based on the check tray observation and body weight sampling. Four check trays were installed in each pond for monitoring feed intake. The required amount of feed were dispensed at certain interval in 24 hours period as follows- $25 \%$ in the morning $(6.00 \mathrm{am}), 20 \%$ at noon $(11.00 \mathrm{pm}), 30 \%$ at evening $(6.00 \mathrm{pm})$ and $25 \%$ at night $(10.00 \mathrm{pm})$. The feed was broadcasted by rope method.

Additional water exchange was not done for the first 60 days. After that $12 \mathrm{~cm}$ of water was added regularly in every 15 days interval till harvesting begins. After 15 days of stocking, sampling of shrimp was done weekly during early hours of the day with a cast net and weights are recorded. Survival rate and average body weight $(\mathrm{ABW})$ of the shrimp were estimated and condition of shrimp health was observed.

All data were analyzed statistically using GraphPad Prism 5 statistical software (GraphPad Software, Inc., San Diego, CA) after they were checked for normal distribution and homogeneity of variance. Only percent data had to be arcsine transformed before analysis; however, non-transformed data are presented in tables. A student t-test was used to examine treatment effects on weight gain, survival, growth and production. All statistical analyses were considered significant at $5 \%(P<0.05)$.

\section{Results}

The salinity was found between $08-18$ ppt during the culture period. The temperature of the water was ranged between 27 to $33^{\circ} \mathrm{C}$ during entire culture period. Transparency ranged from 25 to $55 \mathrm{~cm}$ in probiotics ponds and 20 to $65 \mathrm{~cm}$ in controlled ponds respectively during the culture period. The average $\mathrm{pH}$ was 7.5 to 8.8 in probiotics pond and 7.2 to 9.5 in controlled ponds during the culture time. The alkalinity was measured in $130 / 130$ to $130 / 110$ and $80 / 80$ to $130 / 130$ in probiotics and controlled ponds, respectively. TAN was 0 to $1.0 \mathrm{mg} / \mathrm{l}$ in probiotics ponds and 0 to $4.0 \mathrm{mg} / \mathrm{l}$ in controlled ponds in the culture period. The dissolved oxygen was recorded maximum $8.0 \mathrm{ppm}$ and minimum $4.5 \mathrm{ppm}$ in probiotics ponds and maximum $7.0 \mathrm{ppm}$ and minimum $4.0 \mathrm{ppm}$ in controlled ponds (Table 1). 
Table 1. Water quality parameters of Probiotic treated and control ponds during culture period.

\begin{tabular}{|c|c|c|c|c|c|c|c|c|c|c|}
\hline \multirow{3}{*}{$\begin{array}{c}\text { Weekly } \\
\text { sampling }\end{array}$} & \multicolumn{2}{|c|}{ Salinity } & \multicolumn{2}{|c|}{ Temperature } & \multicolumn{2}{|c|}{$\mathrm{pH}$} & \multicolumn{2}{|c|}{ Dissolved oxygen } & \multicolumn{2}{|c|}{$\begin{array}{l}\text { Total ammonia nitrogen } \\
\text { (TAN) }\end{array}$} \\
\hline & Treated & Control & Treated & Control & Treated & Control & Treated & Control & Treated & Control \\
\hline & Avg. \pm SD & Avg. \pm SD & Avg. \pm SD & Avg. \pm SD & Avg. \pm SD & Avg. \pm SD & Avg. \pm SD & Avg. \pm SD & Avg. \pm SD & 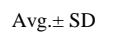 \\
\hline 1 st & $17 \pm 0.6$ & $17 \pm 0.6$ & $30 \pm 0.6$ & $30 \pm 0.6$ & $8.1 \pm 0.5$ & $7.6 \pm 0.3$ & $5.5 \pm 0.5$ & $5.3 \pm 0.6$ & $0.4 \pm 0.4$ & $2.7 \pm 0.6$ \\
\hline $2 \mathrm{nd}$ & $18 \pm 0.6$ & $18 \pm 0.0$ & $30 \pm 1.0$ & $28 \pm 1.5$ & $8.6 \pm 0.3$ & $8.7 \pm 0.2$ & $4.7 \pm 1.2$ & $4.8 \pm 0.8$ & $0.5 \pm 0.2$ & $2.9 \pm 0.7$ \\
\hline $3 \mathrm{rd}$ & $18 \pm 0.6$ & $17 \pm 0.0$ & $30 \pm 0.6$ & $30 \pm 0.6$ & $8.4 \pm 0.3$ & $8.6 \pm 0.2$ & $5.2 \pm 0.3$ & $5.5 \pm 0.5$ & $0.5 \pm 0.2$ & $2.2 \pm 0.5$ \\
\hline 4th & $15 \pm 0.6$ & $15 \pm 0.6$ & $29 \pm 0.6$ & $30 \pm 0.6$ & $8.6 \pm 0.1$ & $8.3 \pm 0.3$ & $6.2 \pm 0.3$ & $6.0 \pm 0.5$ & $0.60 .2 \pm$ & $2.5 \pm 0.9$ \\
\hline 5th & $15 \pm 1.0$ & $14 \pm 0.6$ & $30 \pm 1.0$ & $29 \pm 1.2$ & $8.7 \pm 0.4$ & $8.8 \pm 0.2$ & $5.2 \pm 0.3$ & $4.7 \pm 0.6$ & $0.6 \pm 0.1$ & $2.6 \pm 0.8$ \\
\hline 6th & $14 \pm 0.6$ & $14 \pm 0.6$ & $29 \pm 1.5$ & $30 \pm 0.6$ & $8.3 \pm 0.2$ & $8.5 \pm 0.2$ & $6.2 \pm 0.3$ & $5.7 \pm 1.0$ & $0.5 \pm 0.3$ & $2.8 \pm 0.7$ \\
\hline 7th & $14 \pm 0.6$ & $13 \pm 0.6$ & $27 \pm 0.6$ & $30 \pm 1.5$ & $8.4 \pm 0.3$ & $8.0 \pm 0.1$ & $4.3 \pm 0.6$ & $5.0 \pm 0.5$ & $0.3 \pm 0.2$ & $2.1 \pm 0.2$ \\
\hline 8th & $12 \pm 1.0$ & $12 \pm 0.6$ & $28 \pm 0.6$ & $28 \pm 1.2$ & $8.1 \pm 0.2$ & $8.3 \pm 0.2$ & $4.3 \pm 0.6$ & $4.8 \pm 0.3$ & $0.8 \pm 0.2$ & $2.0 \pm 0.7$ \\
\hline 9th & $11 \pm 0.6$ & $11 \pm 1.0$ & $26 \pm 1.0$ & $26 \pm 1.0$ & $8.0 \pm 0.3$ & $8.1 \pm 0.3$ & $5.2 \pm 0.3$ & $5.0 \pm 0.5$ & $0.4 \pm 0.2$ & $2.0 \pm 0.6$ \\
\hline 10th & $10 \pm 0.6$ & $10 \pm 0.0$ & $29 \pm 1.5$ & $30 \pm 1.0$ & $8.1 \pm 0.3$ & $8.1 \pm 0.3$ & $6.2 \pm 0.3$ & $6.0 \pm 0.5$ & $0.3 \pm 0.2$ & $2.1 \pm 0.5$ \\
\hline 11th & $10 \pm 0.6$ & $10 \pm 0.0$ & $28 \pm 0.6$ & $28 \pm 0.6$ & $8.8 \pm 0.2$ & $8.8 \pm 0.2$ & $4.3 \pm 0.6$ & $4.8 \pm 0.3$ & $0.3 \pm 0.5$ & $2.3 \pm 0.4$ \\
\hline 12th & $9 \pm 1.0$ & $9 \pm 0.0$ & $24 \pm 0.6$ & $25 \pm 1.2$ & $8.8 \pm 0.2$ & $8.8 \pm 0.2$ & $4.3 \pm 0.6$ & $4.7 \pm 0.6$ & $0.6 \pm 0.4$ & $2.4 \pm 0.4$ \\
\hline 13th & $8 \pm 0.6$ & $8 \pm 0.6$ & $27 \pm 1.2$ & $27 \pm 1.2$ & $8.5 \pm 0.3$ & $8.5 \pm 0.3$ & $4.5 \pm 0.9$ & $5.2 \pm 0.6$ & $0.6 \pm 0.3$ & $2.3 \pm 0.4$ \\
\hline 14th & $8 \pm 0.6$ & $8 \pm 0.6$ & $28 \pm 1.5$ & $30 \pm 0.6$ & $8.6 \pm 0.1$ & $8.7 \pm 0.1$ & $5.3 \pm 0.3$ & $5.2 \pm 0.3$ & $0.2 \pm 0.3$ & $2.4 \pm 0.6$ \\
\hline
\end{tabular}

SD: Standard deviation

The average final body weight of the harvested shrimp was $37.67 \pm 1.15 \mathrm{~g}$ and $27.33 \pm 0.58$ $\mathrm{g}$ in probiotics and controlled ponds, respectively. The average survival rate was $90.67 \pm 1.15$ $\%$ in probiotics ponds and $71.00 \pm 3.0 \%$ in controlled ponds. The average daily weight gain was $0.27 \pm 0.01 \mathrm{~g}$ and $0.19 \pm 0.01 \mathrm{~g}$ in probiotics and controlled ponds. Average per hectare production was $4385.67 \pm 116.10 \mathrm{~kg}$ and $2557.67 \pm 108.74 \mathrm{~kg}$ in probiotics and controlled ponds (Table 2).

Table 2. Growth and survival rate (\%) of $P$. monodon in probiotics ponds.

\begin{tabular}{|c|c|c|c|c|c|c|c|c|}
\hline \multirow{2}{*}{ Particulars } & \multicolumn{4}{|c|}{ Probiotics ponds } & \multicolumn{4}{|c|}{ Controlled ponds } \\
\hline & 1 & 2 & 3 & Avg. \pm SD & 1 & 2 & 3 & Avg. \pm SD \\
\hline $\begin{array}{l}\text { Stocking } \\
\text { (number. } / \mathrm{m}^{2} \text { ) }\end{array}$ & 13 & 13 & 13 & $13 \pm 0.0$ & 13 & 13 & 13 & $13 \pm 0.0$ \\
\hline $\begin{array}{l}\text { Initial weight } \\
(\mathrm{mg})\end{array}$ & 4.68 & 4.85 & 4.72 & $4.75 \pm 0.09$ & 4.78 & 4.82 & 4.64 & $4.75 \pm 0.09$ \\
\hline DOC & 135 & 137 & 137 & $136.33 \pm 1.15$ & 138 & 135 & 136 & $136.33 \pm 1.53$ \\
\hline Survival (\%) & 92 & 90 & 90 & $90.67 \pm 1.15$ & 71 & 68 & 74 & $71.00 \pm 3.00$ \\
\hline $\begin{array}{l}\text { Final weight } \\
\text { (gm) }\end{array}$ & 37 & 39 & 37 & $37.67 \pm 1.15$ & 27 & 28 & 27 & $27.33 \pm 0.58$ \\
\hline $\mathrm{ADG}(\mathrm{gm})$ & 0.27 & 0.28 & 0.27 & $0.27 \pm 0.01$ & 0.19 & 0.2 & 0.19 & $0.19 \pm 0.01$ \\
\hline $\begin{array}{l}\text { Harvest } \\
\text { (kg/ha) }\end{array}$ & 4372 & 4508 & 4277 & $4385.67 \pm 116.10$ & 2662 & 2445 & 2566 & $2557.67 \pm 108.74$ \\
\hline
\end{tabular}

DOC: Days of culture; ADG: Average daily growth; SD: Standard deviation 
The average body weight (gm) of the shrimps is significantly higher in the ponds with probiotics than that of control ponds (Student $t$-test, Two tailed, degree of freedom $(\mathrm{df})=13, P$ $<0.01)$. It increases when the culture period extends and this increase is higher in probiotics treated ponds rather than control ponds (Table 3).

Table 3. Weekly Growth of $P$. monodon in the culture ponds*.

\begin{tabular}{|c|c|c|c|c|c|c|c|c|}
\hline \multirow{2}{*}{$\begin{array}{l}\text { Weekly } \\
\text { growth }\end{array}$} & \multicolumn{4}{|c|}{ Probiotics ponds } & \multicolumn{4}{|c|}{ Controlled ponds } \\
\hline & 1 & 2 & 3 & Avg. \pm SD & 1 & 2 & 3 & Avg. \pm SD \\
\hline 1 st & 4 & 5 & 4 & $4.33 \pm 0.58$ & 3 & 3 & 2.5 & $2.83 \pm 0.29$ \\
\hline 2nd & 7 & 7 & 6.5 & $6.83 \pm 0.29$ & 4 & 4.5 & 4 & $4.17 \pm 0.29$ \\
\hline $3 r d$ & 9 & 9 & 8.5 & $8.83 \pm 0.29$ & 6 & 6 & 6 & $6.00 \pm 0.00$ \\
\hline 4 th & 12 & 12 & 11 & $11.67 \pm 0.58$ & 7.5 & 8 & 9 & $8.17 \pm 0.76$ \\
\hline 5 th & 14 & 15 & 14 & $14.33 \pm 0.58$ & 9.5 & 11 & 11 & $10.50 \pm 0.87$ \\
\hline 6th & 16 & 19 & 17 & $17.33 \pm 1.53$ & 12 & 12 & 10.5 & $11.50 \pm 0.87$ \\
\hline 7 th & 19 & 21 & 20 & $20.00 \pm 1.00$ & 14 & 15 & 12 & $13.67 \pm 1.53$ \\
\hline 8th & 22 & 23.5 & 22.5 & $22.67 \pm 0.76$ & 15.5 & 17 & 14 & $15.50 \pm 1.50$ \\
\hline 9th & 25 & 26 & 25 & $25.33 \pm 0.58$ & 18 & 19 & 16 & $17.67 \pm 1.53$ \\
\hline 10th & 27 & 29 & 27 & $27.67 \pm 1.15$ & 21 & 20 & 18.5 & $19.83 \pm 1.26$ \\
\hline 11th & 30 & 32 & 29.5 & $30.50 \pm 1.32$ & 22 & 23 & 20 & $21.67 \pm 1.53$ \\
\hline 12 th & 32 & 34 & 31.5 & $32.50 \pm 1.32$ & 24 & 25 & 23 & $24.00 \pm 1.00$ \\
\hline 13th & 35 & 36 & 34 & $35.00 \pm 1.00$ & 26 & 26 & 25 & $25.67 \pm 0.58$ \\
\hline 14th & 37 & 39 & 37 & $37.67 \pm 1.15$ & 27 & 28 & 27 & $27.33 \pm 0.58$ \\
\hline
\end{tabular}

*First samplings were done after 30 days of culture period

\section{Discussion}

Information on the efficiency of probiotics on the growth and survival of the cultivable shrimp species, $P$. monodon is not adequate and this study was conducted to observe the efficiency of probiotics (pH Fixer, Super Biotic, Super P S, Mutagen, Zymetin, Pro-w and Pro-2) on the growth and survival of the cultivable shrimp species, $P$. monodon and also to monitor its influence on important water quality parameters. Salinity, temperature, dissolved oxygen, $\mathrm{pH}$ and total ammonia nitrogen (TAN) are important water quality parameters considered during the study. Water quality parameters were found more suitable in probiotics ponds than in controlled ponds those matches with the report of Jiravanichpaisal et al. [24]. Maintenance of good water quality is essential for optimum growth and survival of shrimps [21].

In the present study the salinity of probiotic ponds ranged from 8-18 ppt. According to Soundarapandian et al. [21] salinity is an important parameter in maintaining optimum growth and survival of shrimps. Even though, P. monodon is euryhaline aquatic species; it is comfortable when exposed to optimum salinity. At high salinity the shrimp grows slowly but remains healthy and resistant to diseases. If the salinity is low, the shell becomes weak and prone to diseases. Muthu [25], Soundarapandian and Gunalan [26] and Karthikeyan [27] recommended an ideal salinity range of $10-35 \mathrm{ppt}$ for $P$. monodon culture. While 
Chanratchkool et al. [28] maintained the salinity in between 10-30 ppt. Soundarapandian et al. [21] stated in their study that $\mathrm{pH}$ is one of the vital environmental characteristics, which affects the metabolism and other physiological process of shrimps. In their study $\mathrm{pH}$ range was 7.6 to 8.2 for the probiotics treated and control ponds. In the present study $\mathrm{pH}$ range was 8-8.8 in probiotic ponds and 7.6-8.8 in controlled ponds. Ramanathan et al. [29] said that the optimum range of $\mathrm{pH} 6.8$ to 8.7 should be maintained for maximum growth and production. Dissolved oxygen plays an important role on growth and production through its direct effect on feed consumption and maturation and low levels of dissolved oxygen can cause damages in oxidation state of substances from the oxidized to the reduced form. In the present study dissolved oxygen was found 4.3-6.2 ppm and 4.7-6 ppm in probiotic and controlled ponds respectively. Soundarapandian et al. [21] found 3.2 to $4.2 \mathrm{ppm}$ dissolved oxygen in all their culture ponds that is close to the present study. Low-level of oxygen hampers metabolic performances in shrimp and can reduce growth and moulting and also causes mortality [30]. Water temperature is the most important environmental variables in shrimp cultures, because it directly affects metabolism, oxygen consumption, growth, moulting and survival [21]. The optimum range of temperature for $P$. monodon culture is between 26 to $33^{\circ} \mathrm{C}[31,26]$. In this study temperature range was found $24-30^{\circ} \mathrm{C}$ and $25-30^{\circ} \mathrm{C}$ in probiotic and controlled pond respectively which was maintained within reference ranges. So it was observed that probiotic does not alter water temperature or it does not have any beneficial effect on it. Ammonia builds up in the water of the fish pond when nitrogen-containing substances decay. The two main nitrogen sources in culturable fish ponds are the waste excretions from the fish and uneaten food. One of the breakdown products of both these substances is ammonia. At farm level, Ammonia level should be less than $1 \mathrm{ppm}$ [21]. In the present study total ammonia nitrogen was $0.2-0.8$ and 2-2.9 in probiotic and controlled ponds respectively. Thus maintaining the ammonia level probiotic helps in maintaining good water quality and thereby keeps the shrimp disease free.

The average body weight of the harvested shrimp was $37.67 \pm 1.15 \mathrm{~g}$ and $27.33 \pm 0.58 \mathrm{~g}$ in probiotics and controlled ponds, respectively and the difference was significant between these two productions (Student t-test, Two tailed, $\mathrm{df}=13, P<0.01$ ). The average daily growth (ADG) was 1.42 times better in probiotic pond than in the control pond whereas per hectare total production was 1.72 times better in probiotic than control pond. Result showed that all probiotic- supplemented diets resulted in higher growth in prawn than the control diet though the amount of feeding was same in both the ponds. This result is very inspiring in shrimp culture with probiotics as size of shrimp is directly related to better foreign exchange earnings. Maeda and Nagami [32] observed that bacterial strains possessing vibrio static activity improved the growth of prawn and crab larvae. Zhenguo et al. [33] found that photosynthetic bacteria used in prawn food or culture water improved the growth of the prawn. More or less same result was found by Saad et al. [34].

In the present study the average survival rate was $90.67 \pm 1.15 \%$ in probiotics ponds and $71.00 \pm 3.0 \%$ in controlled ponds and the difference was significant between these two productions (Student t-test, Two tailed, $\mathrm{df}=13, P<0.01$ ). In probiotic ponds survival rate was $19.67 \%$ more than control ponds. Here in this study with the application of probiotics, survival rate of shrimp has been found more compared to the controlled ponds which is similar to the report of Garriques and Arevalo [35]. According to these authors the use of V. alginolyticus as a probiotic agent increases survival and growth in $P$. vannamei postlarvae by competitive 
elimination of potential pathogenic bacteria, and also effectively reduces the need for antibiotic prophylaxis in intensive larvae culture system. Maeda and Liao [36] also found higher survival and molt rates of prawn larvae of P. monodon by treating the pond with soil extract and the bacterial strain. A farm on Negros, in the Philippines, which had been devastated by luminous Vibrio disease while using heavy doses of antibiotic in feed, achieved survival of $80-100 \%$ of shrimp in all ponds treated with probiotics [66].

\section{Conclusion}

The general conclusion obtained from the present study is that the probiotic plays a vital role in growth, survival and disease resistance of the aquatic animal by maintaining good water quality parameters throughout the culture period. Probiotic treatment offers a promising alternative to the antibiotics for fish and shrimp aquaculture system. In Bangladesh sustainable shrimp culture with probiotics is increasing day by day and unemployment can be mitigated through this sector. Further research is still needed to detect the mode of action of probiotic on $P$. monodon digestibility and its effect on immune response and stress resistance.

\section{References}

1. R. Fuller, Probiotics: The Scientific basis (Chapman and Hall, London, UK, 1992) p. 398.

2. A. Farzanfar, FEMS Immunol Med Microbiol. 48(2), 149 (2006). http://dx.doi.org/10.1111/j.1574-695X.2006.00116.x PMid:17064272

3. R. Havenaar, B. T. Brink, and J. H. J. Huis in't Veld, Selection of strains for probiotic use. In: R. Fuller (ed), Probiotics: the scientific basis (Chapman and Hall, London, 1992) pp. 209-224.

4. DoF (Department of Fisheries), Unnata projuktite bagda chingri chas sohayeka (Matshabhabon, Ramna, Dhaka, Bangladesh, 2012).

5. A. K. Jha, J. Bang. Acad. Sci. 35 (2), 237 (2011).

6. D. J. W. Moriarty, O. Decamp, and P. Lavens, Probiotics in Aquaculture (Aquaculture Asia Pacific Magazine, 2005) pp. 14-16.

7. D. J. W. Moriarty, Aquaculture 164, 351 (1998). http://dx.doi.org/10.1016/S0044-8486(98)00199-9

8. S. Ziaei-Nejad, M. H. Rezaei, G. A. Takami, D. L. Lovett, A. Mirvaghefi, and M. Shakouri, Aquaculture 252, 516 (2006). http://dx.doi.org/10.1016/j.aquaculture.2005.07.021

9. B. Vaseeharan and P. Ramasamy, Lett. Appl. Microbiol. 36, 83 (2003). http://dx.doi.org/10.1046/j.1472-765X.2003.01255.x PMid: 12535126

10. D. J. W. Moriarty, Disease control in shrimp aquaculture with probiotic bacteria- Proceedings of the 8th International Symposium on Microbial Ecology, Atlantic Canada Society for Microbial Ecology (Halifax, Canada, 1999) pp. 237-243.

11. D. Garriques and G. Arevalo, An evaluation of the production and use of a live bacterial isolate to manipulate the microbial flora in the commercial production of Penaeus vannamei postlarvae in Ecuador. In: C. L. Browdy and J. S. Hopkins (ed.), Swimming through troubled water. Proceedings of the Special Session on Shrimp Farming, Aquaculture (World Aquaculture Society, Baton Rouge, La, 1995) pp. 53-59.

12. S. V. Alavandi, K. K. Vijayan, T. C. Santiago, M. Poornima, K. P. Jithendran, S. A. Ali, and J. J. S. Rajan, Fish and Shellfish Immunology 17, 115 (2004). http://dx.doi.org/10.1016/j.fsi.2003.11.007 PMid: 15212731

13. K. K. Vijayan, I. S. B. Singh, N. S. Jayaprakash, S. V. Alavandi, S. S. Pai, R. Preetha, J. J. S. Rajan, and T. C. Santiago, Aquaculture 251, 192 (2006). http://dx.doi.org/10.1016/j.aquaculture.2005.10.010

14. F. J. Gatesoupe, Aquaculture 180, 147 (1999). http://dx.doi.org/10.1016/S0044-8486(99)00187-8 
15. S. Rengpipat, S. Rukpratanporn, S. Piyatiratitivorakul, and P. Menasveta, Probiotics in Aquaculture: A Case Study of Probiotics for Larvae of the Black Tiger Shrimp (Penaeus monodon). In: Flegel TW(ed) Advances in shrimp biotechnology (National Center for Genetic Engineering and Biotechnology, Bangkok, 1998) pp. 177-181.

16. L. Vershuere, G. Rombaut, P. Sorgeloos, and W. Verstraete, Microbiol. Mol. Biol. Rev. 64, 655 (2000). http://dx.doi.org/10.1128/MMBR.64.4.655-671.2000

17. B. Gomez-Gil, A. Roque, and J. Turnbull, Aquaculture 191, 259 (2000). http://dx.doi.org/10.1016/S0044-8486(00)00431-2

18. A. Irianto and B. Austin, J. Fish Dis. 25, 633 (2002). http://dx.doi.org/10.1046/j.1365-2761.2002.00422.x

19. N. G. Vine, W. D. Leukes, and H. Kaiser, FEMS Microbiol. Rev. 30, 404 (2006). http://dx.doi.org/10.1111/j.1574-6976.2006.00017.x PMid:16594964

20. P. Soundarapandian and S. Sankar, Int. J. Zool. Res. 4(1), 35 (2008). http://dx.doi.org/10.3923/ijzr.2008.35.41

21. P. Soundarapandian, V. Ramanan, and G. K. Dinakaran, Current Res. J. Soc. Sci. 2 (2), 51 (2010).

22. D. J. W. Moriarty, Aquaculture 151, 333 (1997). http://dx.doi.org/10.1016/S0044-8486(96)01487-1

23. S. N. Chen, S. L. Huang, and G. H. Kou, Studies on the epizootiology and pathogenicity of bacterial infections in cultured giant tiger prawns, Penaeus monodon in Taiwan. Paper presented at the proceedings of the Workshop, Diseases of cultured Penaeid Shrimp in Asia and the United States, Hawai (1992) p.195.

24. P. Jiravanichpaisal, P. Chuaychuwong, and P. Menasveta, The use of Lactobacillus sp. as the probiotic bacteria in the giant tiger shrimp (Penaeus monodon Fabricius), Poster session of the 2nd Asia-Pacific marine biotechnology conference and 3rd Asia-pacific conference on algal biotechnology, Phuket Thailand (May, 1997) p. 16.

25. M. S. Muthu, Site selection and type of farms for coastal aquaculture of prawns, Proceedings of the Symposium on shrimp farming (Bombay, Marine Products Export Development Authority, 1980) pp. 97-106.

26. P. Soundarapandian and B. Gunalan, Int. J. Zool. Res. 4(1), 21 (2008). http://dx.doi.org/10.3923/ijzr.2008.21.27

27. J. Karthikeyan, Aquaculture (shrimp farming) its influence on environment, Technical paper submitted to the seminar 'Our Environment-its challenges to development projects', American Civil Engineers, Calcutta, India (September 1994).

28. P. Chanratchkool, J. F. Turunbull, and C. Limsunean, Health management in Shrimp ponds, Aquatic Health Research Institute, Department of Fisheries, Kasetasart University, Bankok (1994) p. 91.

29. N. Ramanathan, P. Padmavathy, T. Francis, S. Athithian, and N. Selvaranjitham, Manual on polyculture of tiger shrimp and carps in freshwater, Tamil Nadu Veterinary and Animal Sciences University, Fisheries College and Research Institute, Thothukudi (2005) pp. 1-161.

30. L. M. Gilles, Environmental factors affect immune response and resistance in Crustaceans, the Advocate (2001) p. 18.

31. C. E. Boyd, Fisheries World 3, 33 (1995).

32. M. Maeda and K. Nogami, Some aspects of the biocontrolling method in aquaculture, Current topics in marine biotechnology (Japan. Soc. Mar. Biotechnol, Tokyo 1989) pp. 395-397.

33. Q. Zhenguo, T. Ruiying, and H. Ningyu, Marine Sci. 2, 4 (1992).

34. A. S. Saad, M. M. Habashy, and K. M. Sharshar, World Appl. Sci. J. 6 (4), 550 (2009).

35. D. Garriques and G. Arevalo, An evaluation of the production and use of a live bacterial isolate to manipulate the microbial flora in the commercial production of Penaeus vannzamei postlarvae in Ecuador, Eds. C. L. Browdy and J. S. Hopkins, Swimming through troubled water, proceedings of the special session on shrimp farming (World Aquaculture Society, 1995) pp. 53-59.

36. M. Maeda and I. C. Liao, Aquaculture 21, 25 (1992). 